\title{
ТРЕТ НАТПРЕВАР ПО ХЕМИЈА ЗА УЧЕНИЦИ ОД СРЕДНИТЕ УЧИЛИШТА ОД РЕПУБЛИКА МАКЕДОНИЈА
}

Секцијата за хемиско образование при Сојузот на хемичарите и технолозите на Македонија во 2014 година е акредитирана од МОН за организација на натпревари по хемија за ученици од средните училишта од Република Македонија. Оваа година се одржа третиот натпревар.

Натреварите за учениците се организираат и одржуваат во четири категории:

I - Категорија според наставната програма по хемија за I год. гимназиско образование

II - Категорија според наставната програма по хемија за II год. гимназиско образование

III - Категорија според наставната програма по хемија за III год. гимназиско образование

IV - Категорија според наставната програма по хемија за IV год. гимназиско образование

Оваа учебна година за натпреварот се пријавија вкупно 468 ученици од 50 средни училишта од Македонија. Општинските натпревари се одржаа на 12 март, а регионалните натпревари се одржаа на 9 април 2016 година во следниве училишта:

- Регион 1 (Скопје): СУГС Гимназија Раде Јовчевски-Корчагин.

- Регион 2 (Куманово, Крива Паланка, Кратово, Пробиштип, Свети Николе): СОУ Гимназија Гоце Делчев, Куманово.

- Регион 3 (Охрид, Струга, Кичево, Гостивар, Тетово, Маврово и Ростуша): ПСУ Јахја Кемал Колеџ, Струга.

- Регион 4 (Велес, Кавадарци, Гевгелија, Валандово): СОУ Гимназија Добри Даскалов, Кавадарци.

- Регион 5 (Прилеп, Битола, Крушево, Ресен, Демир Хисар): СОУ Гимназија Мирче Ацев, Прилеп.

- Регион 6 (Штип, Струмица, Берово, Виница, Радовиш, Македонска Каменица): СОУ Гимназија Славчо Стојменски, Штип.

Државниот натпревар се одржа на 14 мај 2016 год. во Институтот за хемија при ПМФ, Скопје. Според Правилникот за организација и реализација на натпревари по хемија за ученици од средното образование, благодарници за учество на државниот натпревар добија сите учесници, а со дипломи од СХТМ беа наградени најдобро пласираните три ученици и нивните ментори од соодветна категорија:

І категорија

\begin{tabular}{c|l|c|l|ll}
\hline $\begin{array}{c}\text { Плас- } \\
\text { ман }\end{array}$ & $\begin{array}{l}\text { Име и презиме на } \\
\text { ученик }\end{array}$ & Поени & Училиште & Ментор & Општина \\
\hline 1 & Јован Петрески & 46 & ПСУ Јахја Кемал & Емел Шериф Мифтар Бутел \\
\hline 2 & Кристијан Трајковски & 44 & СОУ Гимназија Гоце Делчев & Лена Николовска & Куманово \\
\hline 3 & Стефран Стојковиќ & 43 & $\begin{array}{l}\text { СУГС Гимназија Раде Јовчевски- } \\
\text { Корчагин }\end{array}$ & $\begin{array}{l}\text { Гордана Геческа } \\
\text { Скопје }\end{array}$ \\
\hline
\end{tabular}

II категорија

\begin{tabular}{c|l|c|l|ll}
\hline $\begin{array}{c}\text { Плас- } \\
\text { ман }\end{array}$ & $\begin{array}{l}\text { Име и презиме на } \\
\text { ученик }\end{array}$ & Поени & Училиште & Ментор & Општина \\
\hline 1 & Емил Николов & 40 & СУГС Гимназија Орце Николов & $\begin{array}{l}\text { Елизабета Николовска Карпош } \\
\text { Софрониевска }\end{array}$ \\
\hline 2 & Њомза Селмани & 39 & ПСУ Јахја Кемал & Меника Анастасиеска Карпош \\
\cline { 2 - 6 } 3 & Магдалена Златанова & 37 & ПСУ Јахја Кемал & Хакан Ипек & Струмица \\
\hline
\end{tabular}


III категорија

\begin{tabular}{c|l|c|l|lc}
\hline $\begin{array}{c}\text { Плас- } \\
\text { ман }\end{array}$ & $\begin{array}{l}\text { Име и презиме на } \\
\text { учник }\end{array}$ & Поени & Училиште & Ментор & Општина \\
\hline 1 & Филип Трајковски & 48 & $\begin{array}{l}\text { СУГС Гимназија Раде } \\
\text { Јовчевски-Корчагин }\end{array}$ & Гордана Геческа & Центар \\
\hline 2 & Денис Рајхл & 45 & ПСУ Јахја Кемал & Аксу Самет & Гази Баба \\
\hline 3 & Ивана Тодоровска & 42 & $\begin{array}{l}\text { СОУ Гимназија Јосип Броз } \\
\text { Тито }\end{array}$ & Борис Маслинко & Битола \\
\hline
\end{tabular}

IV категорија

\begin{tabular}{c|l|c|l|ll|}
\hline $\begin{array}{c}\text { Плас- } \\
\text { ман }\end{array}$ & $\begin{array}{l}\text { Уме и презик } \\
\text { учене на }\end{array}$ & Поени & Училиште & Ментор & Општина \\
\hline 1 & Зоран Гаврилов & 45 & СОУ Јане Сандански & Панди Јовевска & Штип \\
\hline 2 & Кристијан Топалов & 43 & СОУ Љупчо Сантов & Драги Јакимов & Кочани \\
\hline 3 & Горјан Стојков & 37.5 & ПСУ Јахја Кемал & Емел Шериф Мифтар Бутел \\
\hline
\end{tabular}

Учениците кои освоија прво место беа наградени и со книги (учебници по хемија од реномирани странски издавачи на англиски јазик), а на сите учесници на државниот натпревар СХТМ им подари маици.

Во организацијата и реализација на овие натпревари беа вклучени членовите на Државната комисија за натпревари по хемија: проф. д-р Марина Стефова (раководител на Секцијата за хемиско образование и координатор на натпреварите по хемија за средно образование), проф. д-р Владимир Петрушевски, проф. д-р Слоботка Алексовска, доц. д-р Наташа Ристовска, Јане Богданов, доц. д-р Марина Стојановска, доц. д-р Миха Буклески, доц. д-р Јасмина Петреска Станоева, доц. д-р Сандра Димитровска-Лазова (сите од Институтот за хемија), Аријанит Река (од Катедрата за хемија при Државниот универзитет во Тетово) и Иванка Мијиќ (советник по хемија во Бирото за развој на образованието), како и Милена Колевска (технички соработник во Институтот за хемија) и студентите по хемија Емилија Јанкуловска, Наташа Дупкарова, Сара Глигороска, Зорица Георгиева, Елисавета Николоска, Пеце Шеровски, Ивона Аврамоска, Елена Илиева, Митко Стефановски, Бранко Велевски, Стефран Јованов, Максим Игески, Михаела Анѓелеска. Овие студенти по хемија, кои членуваат и во Клубот на студенти при СХТМ, покрај помошта во реализацијата на натпреварот, одржаа и хемиски спектакл за натпреварувачите веднаш по натпреварот, кој беше извонредно прифатен од учесниците.

Ова беше третиот натпревар по хемија за ученици од средните училишта организиран од Сојузот на хемичарите и технолозите на Македонија со учество на Институтот за хемија при Природно-математичкиот фракултет во Скопје и тоа станува редовна активност која ќе продолжи натаму со цел развивање на интерес и мотивирање на младите да учат и да ја сакаат хемијата.

Марина Стефова Институт за хемија, Природно-математички фракултет Скопје marinaiv@pmf.ukim.mk 


\section{ПРВ НАТПРЕВАР ПО ХЕМИЈА ЗА УЧЕНИЦИ ОД ОСНОВНИТЕ УЧИЛИШТА ОД РЕПУБЛИКА МАКЕДОНИЈА}

Секцијата за хемиско образование при Сојузот на хемичарите и технолозите на Македонија во април 2016 година доби акредитација од МОН за организација на натпревари по хемија за ученици од основните училишта од Република Македонија.

Правилата за учество на овој натпревар се дефинирани со посебен Правилник за организација и реализација на натпревари по хемија за учениците од основното образование.

Натпреварите за учениците се организираат и одржуваат во две категории:

Категорија 1 - според наставната програма по хемија за VIII одделение.

Категорија 2 - според наставната програма по хемија за IX одделение.

Регионалните натпревари се одржаа на 14 мај 2016 год. (сабота), по претходно одржани училишни/општински натпревари, односно соодветна селекција на учениците од страна на нивните наставници. Регионалните натпревари по хемија за учениците од основното образование се одржаа во следниве училишта:

- Регион 1: ООУ „Коле Неделковски“, Скопје (координатор Славица Алексовска).

- Регион 2: ООУ „Христијан Карпош“, Куманово (координатор Ивана Димовска Нојковска).

- Регион 3: ООУ „Св. Климент Охридски“, Охрид (координатор Дивна Стрезоска).

- Регион 4: ООУ „Јосип Броз Тито“, Валандово (координатор Габриела Николова).

- Регион 5: ООУ „Гоце Делчев“, Прилеп (координатор Кети Ивановска).

- Регион 6: ООУ „Никола Карев“, Радовиш (координатор Тања Николовска).

Државниот натпревар се одржа на 28.05.2016 год. (сабота) во Институтот за хемија при ПМФ, Скопје. Според Правилникот за организација и реализација на натпревари по хемија за учениците од основното образование, како награда на најдобро пласираните натпреварувачи на државниот натпревар во секоја категорија, СХTM доделува дипломи, според следниве критериуми:
I награда - за освоени 95,0 - 100,0 проценти
II награда - за освоени 88,0 - 94,9 проценти
III награда - за освоени 80,0 - 87,9 проценти
Пофалница - за освоени 70,0 - 79,9 проценти

Учениците кои освоија прва награда беа наградени со книги (подарок од издавачката куќa Арс Ламина), прворангираните ученици - со подарок од Институтот за хемија, а на сите ученици на државниот натпревар СХТМ им подари маици.

Во организација и реализација на овие натпревари беа вклучени повеќе наставници од Институтот за хемија, меѓу кои проф. д-р Марина Стефова (раководител на Секцијата за хемиско образование), доц. д-р Марина Стојановска (координатор на натпреварите по хемија за ученици од основното образование), проф. д-р Владимир Петрушевски, доц. д-р Јасмина Петреска Станоева, доц. д-р Наташа Ристовска, профр. д-р Јане Богданов, проф. д-р Слоботка Алексовска, доц. д-р Сандра Димитровска-Лазова, доц. д-р Миха Буклески, м-р Милена Колевска, Игор Мавромихаилов, проф. д-р Петре Макрески, проф. д-р Љупчо Пејов, профр. д-р Билјана Пејова, проф. д-р Владимир Ивановски, Зулјета Фетаовска, Мазес Мемед, Марија Георгиевска, Дијана Симиќ, Емилија Јанкуловска, Наташа Дупкарова, Сара Глигороска, Зорица Георгиева, Митко Стефановски и Бранко Велевски. Во натпреварите беше вклучена и Иванка Мијиќ, советник по хемија од Бирото за развој на образованието, чија помош беше многу значајна за успешно одвивање на натпреварите. 
Според максимално постигнатиот број бодови во соодветната категорија, наградени беа вкупно 44 ученици.

Учениците од VIII одделенија освоија осум први, осум втори и деветнаесет трети награди и тоа:

\begin{tabular}{|c|c|c|c|}
\hline $\begin{array}{l}\text { Награ- } \\
\text { да }\end{array}$ & Име и презиме & Училиште, општина & Ментор \\
\hline I & Борјан Кочковски & ООУ „Владо Тасевски“, Карпош & Сузана Стојанова \\
\hline I & Ана Марија Наумовска & ООУ „Даме Груев“, Битола & Билјана Љубенска \\
\hline I & Делфина Апостолоска & ООУ „Гоце Делчев“, Прилеп & Кети Иваноска \\
\hline I & Мартин Кировски & ООУ „Ванчо Прке“, Штип & Ели Трајчева \\
\hline I & Владимир Шарковски & ООУ „Александар Македонски“, Аеродром & Љупка Лесовска \\
\hline 1 & Елена Василеска & ООУ „Гоце Делчев“, Демир Хисар & Никола Најдовски \\
\hline I & Леонид Сајков & ООУ „Стив Наумов“, Битола & Елица Лазаров \\
\hline I & Сара Стојанова & ООУ „Крсте Петков Мисирков“, Радовиш & Зорка Христова Трајкова \\
\hline II & Дана Доневска & ООУ „Димо Хаџи Димов“, Карпош & Виолета Димитриева \\
\hline II & Ѓоко Бојковски & ООУ „Димо Хаџи Димов“, Карпош & Виолета Димитриева \\
\hline II & Стефранија Секулоска & ООУ „Кочо Рацин“, Прилеп & Катерина Слабакоска \\
\hline II & Берна Асанова & ООУ „Крсте Петков Мисирков“, Радовиш & Зорка Христова Трајкова \\
\hline II & Иван Попјанев & ООУ „Коле Неделковски“, Центар & Славица Алексова \\
\hline II & Христијан Левкоски & ООУ „Единство - Башкими - Бирлик“, Гостивар & Весна Ролевска \\
\hline II & Бојана Кузманоска & ООУ „Гоце Делчев“, Прилеп & Кети Иваноска \\
\hline II & Јована Ваневска & ООУ „Александар Македонски“, Аеродром & Љупка Лесовска \\
\hline III & Елена Стаменковска & ООУ „Дедо Иљо Малешевски“, Берово & Сузана Гашчеовска \\
\hline III & Мартин Ангелевски & ООУ „Гоце Делчев“, Демир Хисар & Никола Најдовски \\
\hline III & Стеваноска Ирина & ООУ „Блаже Конески“, Прилеп & $\begin{array}{l}\text { Павлина Темелкоска } \\
\text { Ристеска }\end{array}$ \\
\hline III & Стојкоски Михаил & ООУ „Блаже Конески“, Прилеп & $\begin{array}{l}\text { Павлина Темелкоска } \\
\text { Ристеска }\end{array}$ \\
\hline III & Даријан Шекеров & ООУ „11 Октомври“, Центар & Марија Апостолова \\
\hline III & Драган Андреевски & ООУ „Димката Ангелов - Габерот“, Кавадарци & Даница Пецова \\
\hline III & Ивана Куновска & ООУ „Св. Кирил и Методиј“, Битола & Наталија Аспров \\
\hline III & Клаудија Кондовска & ООУ „Гоце Делчев“, Демир Хисар & Никола Најдовски \\
\hline III & Андреј Шекеров & ООУ „11 Октомври“, Центар & Марија Апостолова \\
\hline III & Бојан Ристов & ООУ „Крсте Петков Мисирков“, Радовиш & Зорка Христова Трајкова \\
\hline III & Верче Атанасова & ООУ „Крсте Петков Мисирков“, Радовиш & Зорка Христова Трајкова \\
\hline III & Дина Геговска & ООУ „Коле Неделковски“, Центар & Славица Алексова \\
\hline III & Диелза Заими & ООУ „Истикбал“, Тетово & Зија Адеми \\
\hline III & Софрија Китановска & ООУ „Јоаким Крчовски“, Крива Паланка & Дане Ангеловски \\
\hline III & Балканска Деа & ООУ „Страшо Пинџур“, Неготино & Велика Маркова \\
\hline III & Димитар Србиноски & ООУ „Д-р Владимир Полежиноски“, Кичево & Славе Ѓинковски \\
\hline III & Марија Костадинова & ООУ „Страшо Пинџур“, Неготино & Велика Маркова \\
\hline III & Методи Наумовски & ООУ „Јохан Хајнрих Песталоци“, Центар & Славица Алексова \\
\hline III & Мила Саздова & ООУ „Х.Т.Карпош“, Карпош & Даниела Радевска \\
\hline
\end{tabular}


Учениците од IX одделение освоија една прва, четири втори и четири трети награди, и тоа:

\begin{tabular}{clll}
\hline Награда & Име и презиме & Училиште, општина & Ментор \\
\hline I & Стеван Богданов & ООУ „Никола Карев“, Кочани & Весна Богданова - Василева \\
\hline II & Андреј Јанков & ООУ „Коле Неделковски“, Центар & Славица Алексова \\
\hline II & Ева Миленкова & ООУ „Кирил и Методиј“, Свети Николе & Мирјана Наунова \\
\hline II & Ана Ефтимова & ООУ „Димитар Влахов“, Штип & Славица Ефтимова \\
\hline II & Стесан Марковски & ООУ „Горгија Пулевски“, Аеродром & Фотинула Димчевска \\
\hline III & Душан Мерџановси & ООУ „Х.Т.Карпош“, Карпош & Даниела Радевска \\
\hline III & Љупка Науновска & ООУ „Гоце Делчев“, Свети Николе & Катерина Величкова \\
\hline III & Деница Темелкоска & ООУ „Гоце Делчев“, Прилеп & Кети Иваноска \\
\hline III & Дунимаглоска Викторија & ООУ „Блаже Конески“, Прилеп & Павлина Темелкоска \\
\hline \hline
\end{tabular}

Ова беше за првпат реализиран натпревар по хемија за ученици од основните училишта организиран од Сојузот на хемичарите и технолозите на Македонија со учество на Институтот за хемија при Природно-математичкиот факултет во Скопје. Оваа активност ќе продолжи и во следните години со цел развивање на интерес и мотивирање на најмладите за хемијата.

Марина Стојановска Институт за хемија, Природно-математички фракултет Скопје marinam@pmf.ukim.mk 


\section{TPET СЕМИНАР ЗА НАСТАВНИЦИ ПО ХЕМИЈА ОД СРЕДНИТЕ УЧИЛИШТА}

Секцијата за образование при Сојузот на хемичарите и технолозите на Македонија и Институтот за хемија, Природно-математичкиот фракултет, Скопје, организираа семинар за наставници по хемија од средните училишта во Р. Македонија. Семинарот, на којшто присуствуваа 94 наставници, беше реализиран во Институтот за хемија на 26 март 2016 година. Основната цел на Семинарот беше професионален развој на наставниците и збогатување на нивното експериментално искуство, како и размена на идеи меѓу сите учесници на Семинарот.

Тема на Семинарот беше „Експериментирање со прирачни средства“. Беа одржани три предавања:

1. Проф. д-р Владимир Петрушевски - Експериментирање со прирачни средства (преглед и примери).

2. Доц. д-р Марина Стојановска - Малите тајни на големите експериментатори.

3. Група на (не толку) среќни хемичари - Демонстрациони експеримети со примена на прирачни средства.

Во рамките на Семинарот се одржаа и две работилници, во кои активно учество зедоа сите учесници. Активностите планирани за овие работилници беа во врска со изведување хемиски експерименти со прирачни средства, бидејќи еден од најголемите проблеми со кој се сретнуваат наставниците при реализација на наставата е недостиг од средства за експериментирање. Раководители на работилниците беа проф. д-р Слоботка Алексовска, доц. д-р Марина Стојановска и студентите по хемија од Групата на (не толку) среќни хемичари.

Последната сесија на Семинарот беше насловена „Од наставниците за наставниците“. Во овој дел тројца наставници по хемија од средните училишта имаа можност да го пренесат нивното искуство елаборирајќ́ по еден експеримент од нивната наставна практика. Во оваа прилика им изразуваме благодарност на Ела Билинска од СУГС „Никола Карев“ од Скопје, Александра Царовска од ОСУ „Ацо Русковски“ од Берово и Нада Јанковиќ од СУГС „Георги Димитров“ од Скопје.

Поради големиот интерес на наставниците за ваков вид комуникација и доедукација, Секцијата за хемиско образование при СХТМ планира да организира вакви семинари еднаш годишно.

доц. д-р Марина Стојановска Институт за хемија, Природно-математички факултет Скопје mmonkovic@yahoo.com 